\title{
Dante (If. V) y Buster Keaton: el efecto-pantalla y la mediación cómica del deseo
}

\section{Raffaele Pinto}

Universitat de Barcelona

rpinto1951@gmail.com

\section{(c) (1)}

\section{Resumen}

La escena final de la película de Buster Keaton Sherlock Holmes junior es una parodia del dantesco episodio de Francesca da Rimini (If. V). El análisis comparativo de los dos textos permite esbozar una teoria del imaginario moderno por la cual la literatura y el cine colaboran en la secularización de la cultura y la emancipación estética del hombre.

Palabra claves: Dante; Buster Keaton; deseo; ficción; imagen; modernidad.

\section{Riassunto}

La scena finale del film di Buster Keaton Sherlock Holmes junior è una parodia dell'episodio dantesco di Francesca da Rimini (If. V). L'analisi contrastiva dei due testi permette di tracciare una teoria dell'immaginario moderno secondo la quale la letteratura e il cinema collaborano alla secolarizzazione della cultura e all'emancipazione estetica dell'uomo.

Parole chiave: Dante; Buster Keaton; desiderio; fiction; immagine; modernità. 
$\mathrm{L}^{2}$ a última divertida escena de Sherlock Holmes junior (I924) se inspira, de manera bastante explícita, en los versos finales del canto V del Infierno. Buster, el protagonista del melodrama, que alterna su trabajo de operador de cine con la pasión de detective, llegado a la tópica situación del beso final, en su cabina de proyección, besa a la muchacha copiando de la pantalla los gestos del personaje de la película que está proyectando (como Paolo besa a Francesca imitando el gesto de Lanzarote: "Quando leggemmo il disïato riso / esser basciato da cotanto amante, / questi, che mai da me non fia diviso, / la bocca

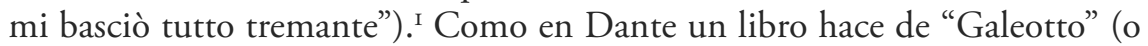
sea, de alcahuete) enseñando a los dos cuñados el arte de amar, así en Keaton una película funciona de modelo para el amante inexperto. También la censura narrativa con la cual Francesca interrumpe púdicamente su relato ("quel giorno più non vi leggemmo avante"), es recogida por Keaton, ya que en el film-modelo hay un brusco corte entre la secuencia del beso y la de la pareja, ya casados, que tienen dos bebés. El salto de una situación a la otra produce una elipsis que deja a Buster en evidente malestar, privándolo de informaciones y modelos sobre una operación tan delicada y decisiva como la generación de los niños.

Una imitación paródica de los versos dantescos podría ser solo otro capítulo de la precoz recepción cinematográfica de la historia de los dos amantes de Rimini, que, como ha mostrado Amilcare Iannucci, se inicia en los Estados Unidos ya en 1907 (Iannucci 2004). ${ }^{2}$ Obsérvese, sin embargo, que en el film de Keaton no se trata de una versión del trágico suceso que novelescamente cuenta Dante, ya que de la historia narrada en el canto V del Inferno son alusivamente parodiados solamente los versos finales. Conviene hablar, más bien, de una relación intertextual en que la fuente es citada y libremente reutilizada en un contexto temático completamente diferente. Lo cual rinde la cita mucho más significativa, desde el punto de vista de la recepción del texto de Dante, dado que nos muestra no un director frente a una obra clásica que es objeto de interpretación y transcodificación, sino un clásico que subterráneamente revive, como sugestión inventiva, en la estrategia expresiva de un director. Éste no tiene en cuenta el conocimiento previo que el espectador pueda tener de la obra citada; antes bien disimula la cita, ya que no hay nada en la trama del film que recuerde aquella historia dantesca. Al cineasta, evidentemente, le interesa tan solo el episodio de la lectura y el beso, y la relación

I. "Al leer que la risa deseada / era besada por tan gran amante, / éste, que de mí nunca ha de apartarse, / la boca me besó, todo él temblando" (Alighieri 1998).

2. Con la breve película ( 15 ') de William W. Ranous, The Two Brothers / Francesca da Rimini. Pero la primera versión teatral estadounidense (Francesca da Rimini de George H. Boker) es de 1855 . 
entre los dos amantes con el libro, que él transcribe en la relación de Buster con el film que está proyectando en la pantalla ${ }^{3}$. Lo que ha hecho Keaton ha sido sustituir la página con la pantalla, en tanto que equivalentes soportes materiales en las cuales un texto (de palabras y/o imágenes) se proyecta y es leído (o mirado).

La conexión entre las dos obras, inexistente en el plano de la trama, es sin embargo fortísima en el plano de las cuestiones estéticas que en ellas se plantean. La escena final del film de Keaton culmina magistralmente una historia que, con el acostumbrado pretexto melodramático de una contrastada pasión de amor, explora cómicamente la relación existencial del protagonista con la ficción fílmica. De hecho el protagonista entra físicamente (en sueño) en la historia proyectada sobre la pantalla, contraponiendo la rigidez y la pesadez de su cuerpo a la aérea ligereza de las figuras cinematográficas, cosa que lo hace víctima de los arbitrarios cambios de escenario que, a través del montaje, se producen en el film. ${ }^{4}$ Un análogo problema afrontó Dante cuando imaginó (él también en una experiencia presentada como onírica) ${ }^{5}$ de atravesar el más allá con el propio cuerpo, que de este modo era sometido a los estímulos

3. No excluyo la posibilidad que la alusión a la Commedia sea indirecta, es decir, mediada por una de las muchas versiones cinematográficas del episodio de Francesca anteriores al film de Keaton. Se trataría, entonces, no de la recepción del poeta sino de su irradiación. A los fines de la argumentación que desarrollo en este trabajo la diferencia es irrelevante.

4. La agudísima mirada crítica de Keaton tematiza, en estas secuencias oníricas, la pérdida de peso, es decir la conversión en imagen, del cuerpo del actor cinematográfico, desarrollando cómicamente una reflexión que Pirandello había ya hecho en la novela de 1915 Si gira (después rebautizado I quaderni di Serafino Gubbio operatore). Las reflexiones de Pirandello fueron retomadas en el ensayo sobre La obra de arte en la época de su reproducción técnica, de Walter Benjamin (que las leía en Léon Pierre-Quint, Significacion du Cinéma, L'art cinèmatographique, II, Paris 1927, pp.I4-15). Reproduzco la página y la cita, que sacan a la luz la naturaleza artificial y fragmentaria de la imagen fílmica, entendida como el producto de una amputación del cuerpo: "Al cine le importa poco que el intérprete represente a otro ante el público; lo que le importa es que se represente a sí mismo ante el sistema de aparatos. Pirandello ha sido uno de los primeros en percibir esta modificación del intérprete cuando su trabajo es un desempeño sometido a prueba. Poco perjudica el hecho de que las observaciones que hace sobre el asunto en su novela Cuadernos de Serafino Gubbio operador [Pirandello 2007] se limiten a subrayar su aspecto negativo. Menos aún que se refieran al cine mudo, puesto que el cine sonoro no ha cambiado nada fundamental en este asunto. Lo decisivo sigue siendo que se actúa para un sistema de aparatos o, en el caso del cine sonoro, para dos. 'El intérprete de cine', escribe Pirandello, 'se siente como en el exilio. Exiliado no solamente de la escena sino incluso de su propia persona. Percibe con oscuro desconcierto el vacío inexplicable que aparece por el hecho de que su cuerpo se convierte en una imagen muda que tiembla un instante sobre la pantalla para desaparecer inmediatamente en el silencio [...] Es este pequeño sistema de aparatos el que usará su sombra para actuar ante el público; él, por su parte, deberá contentarse con actuar para este sistema”" (Benjamin 2003: 69).

5. "Tant'era pien di sonno a quel punto / che la verace via abbandonai" (If. I II-I2) [Pues tan dormido me hallaba en el punto / que abandoné la senda verdadera]. La cuestión sobre el onirismo della Commedia (o sea la pregunta si el viaje de Dante al más allá es una visión tenida durante el sueño o si cuenta un suceso presuntamente real), sigue siendo, desde los primeros comentaristas del Poema, muy debatida. 
de paisajes que, aunque materialísimos en su dimensión teológica, eran sin embargo virtuales desde el punto de vista de un individuo aún viviente. Y él también debió experimentar, en el cuerpo, los efectos del "montaje" teológico del más allá, con todos los sorprendentes cambios de escenario que eso implica (inverosímiles desde un punto de vista naturalista). La analogía entre las dos situaciones estéticas resultará clara simplemente pensando en este hecho: que es tan milagroso o inverosímil que el personaje Dante vaya con su cuerpo al más allá, cuanto que el personaje Buster lleve consigo su cuerpo a la pantalla. Ambos han de atravesar el umbral que separa la realidad de la ficción. Cierto, la plausibilidad del atravesamiento dantesco está garantizada por el paradigma teológico en el que el poeta opera, mientras que la plausibilidad del atravesamiento de Keaton se debe al registro cómico en que el film se desenvuelve. En ambos casos, sin embargo, se trata de penetrar, con el cuerpo, en una zona ficticia ${ }^{6}$. Parece entonces oportuna una reflexión, como la que aquí propongo, sobre el significado histórico de la relación intertextual entre el cineasta y el poeta, o sea, sobre la larga duración de problemáticas que se revelan culturalmente activas no sólo del lado del cineasta, por el valor que el film atribuye a aquellos versos de la Commedia, sino también del lado del poeta, por la nueva luz en la que su texto se presenta gracias a la cita que de él hace Keaton.

Un primer notable resultado lo obtenemos comparando la lectura de Keaton con el amplio abanico de interpretaciones de los críticos de profesión que han leído el canto V del Inferno. En efecto, si bien no tiene sentido esperarse del actor-director una explícita posición interpretativa respecto al episodio de la Commedia, sin embargo su enfoque implica una elección muy clara de los aspectos que a él le resultan significativos, y por tanto una implícita propensión por una de las muchas lecturas del canto que la filología ha producido. Entre estas una, sobre todo, se revela pertinente para entender a Dante en la perspectiva de Keaton, aquella que da René Girard en el marco de su teoría sobre la mediación del deseo. Me refiero en particular a Girard 1961, ensayo ejemplar de crítica antropológica de la literatura, en el cual dicha teoría fue inicialmente formulada. Aquí no se tendrán en cuenta todos sus elementos e implicaciones conceptuales, sino que se utilizarán solamente, y libremente, sus axiomas centrales.

Puesta la necesidad de un mediador en cada relación de deseo, ${ }^{7}$ el desarrollo de la modernidad, y en particular la secularización de la cultura, consiste

6. Para diferenciar los dos tipos de ficción podríamos decir que si en Dante lo ficticio que el más allá representa es más irreal que falso (porque su contenido existe, pero no en este mundo), en Keaton lo ficticio del film es más falso que irreal (porque su contenido pertenece a este mundo).

7. Según Girard la selección del objeto de deseo se produce, en un sujeto, a partir de la admiración hacia un personaje prestigioso con el cual el sujeto quiere identificarse, personaje que se convierte, así, en mediador del deseo del sujeto. El objeto deseado (concreto o abstracto), 
en el progresivo acercamiento del mediador al sujeto deseante, como ejemplo a imitar o como rival a desafiar. Tal aproximación se reduce hasta anular la distancia y por tanto la trascendencia del modelo, que de externo, es decir miméticamente inaccesible, deviene interno: "Según se va acercando el mediador al sujeto que desea, la trascendencia se aleja... Justamente en la mediación interna se encuentra la verdad profunda de lo moderno". En el Quijote, arquetipo novelesco de la modernidad, las dos parejas "Don Quijote - Amadís" y "Anselmo -Lotario" (protagonistas, estos últimos, del relato El curioso impertinente, uno de los excursus del Quijote $)^{8}$ muestran respectivamente el máximo y el mínimo de distancia entre sujeto y mediador (mediador externo - mediador interno). La verdad novelesca sería así la explicitación de la alteridad que anida en cada deseo, opuesta a la mentira romántica que la disimula, en su ilusión de autonomía y autenticidad del yo deseante.

Objeto de análisis en un estudio monográficamente a ese dedicado (Girard 1978), el canto V del Infierno es incluido por Girard en la serie de los clásicos que muestran al sujeto siendo guiado, en la selección del objeto de su deseo, por un modelo novelesco, que por esto funciona como mediador. El estudioso resume así el problema:

Como sabemos, es Francesca la que cuenta la historia de su enamoramiento. Francesca es la esposa del hermano de Paolo y inicialmente parecen no estar enamorados el uno del otro. Pasan el tiempo leyendo la novela caballeresca "Lancelot du lac", en que la reina Ginebra, empujada por un traidor, Galeoto, se enamora del héroe Lanzarote. En el momento en que el caballero Lanzarote besa a la reina, también Paolo y Francesca se besan. Así ha empezado su amor... Una explicación de Dante está en la frase "Galeotto fu il libro e chi lo scrisse». Cabe decir que los libros no son inocentes, detrás de cada libro hay un autor que intenta seducirte, que hace de manera que tú quieras imitarlo. En mi terminología el libro cumple la función de mediador, de modelo de Paolo y Francesca: su amor es pues en cierto sentido un amor copiado.

La consideración comparativa de la serie de textos que de Dante llega hasta Keaton (y de la cual forman parte entre otros, según Girard, el Julian Sorel de Le rouge et le noir, Madame Bovary, El eterno marido de Dostoyevski, el Marcel de la proustiana Recherche) nos permite aislar el elemento común a todos ellos, o sea el carácter imitativo que el deseo asume en el cuadro de una cultura en la cual el sujeto (lector o espectador) interioriza al otro asumiéndolo como

en tanto que simbólicamente perteneciente al mediador, garantiza la identificación con este (que tiene normalmente una dimensión novelesca). El ejemplo más claro de esta relación es la que se establece entre Don Quijote y Amadís de Gaula: las hazañas que el primero desea realizar tienen la finalidad de identificarle, en la percepción idealizada que Don Quijote tiene de sí mismo, con el admirado modelo novelesco.

8. El tema de los dos amigos que se enamoran de la misma mujer había sido desarrollado por Cervantes también en el episodio de Cimbrio y Silerio, en la Galatea. 
modelo de comportamiento. La modernidad de esta relación con el modelo radica en la dimensión ficticia (novelesca o literaria) del modelo mismo, y se distingue nítidamente de la forma antigua de la mímesis de deseo, cuyos modelos, el héroe y el santo, pertenecen al orden de lo "verdadero", o sea al mito y la religión, que actúan como tales en la conciencia individual y colectiva a partir de la "fe" en sus contenidos. En el momento en que la filosofía o la crítica revelan su dimensión ficticia, se convierten en literatura, y entran ellos también en la dimensión de lo ficticio. Como muestra el episodio de Francesca, Dante ha intuido y representado la nueva función de modelo ideal que la literatura (en tanto que ficción novelesca) adquiere, suplantando el mito y la religión. La sustitución implica un cambio radical de paradigma estético, ya que el héroe y el santo, en tanto que sobrenaturales, son de hecho "inimitables", y por tanto no pueden ser interiorizados como modelos asequibles de comportamiento. Su ejemplaridad es ciertamente fundamental para definir los valores ideológicos de la sociedad y la dirección ética de las conciencias individuales, pero su distancia excluye una identificación mimética total, como la que se observa en los ejemplos literarios (y cinematográficos) antes citados, puesto que tanto el héroe mítico como el santo se sitúan en una dimensión trascendente normalmente inaccesible al lector. Su mediación es, por lo tanto, "externa", según el esquema di Girard, y se opone a la mediación "interna" de la ficción literaria. La novela moderna, y aún más el cine, aproximando el mediador al sujeto, consiente la mimesis del lector-espectador hasta una completa identificación. ${ }^{9}$

Una breve reseña de películas en las cuales la pantalla ejerce esto efecto de sugestión sobre los personajes de la historia que la película cuenta, mostrará la

9. Walter Benjamin, en el marco de su propio modelo hermenéutico (Benjamin 2003: 72), había perfectamente intuido y descrito el radical acercamiento del modelo estético al sujeto deseante, realizado por el cine. Considérense estas observaciones sobre la diferencia entre el actor teatral y el cinematográfico: "Las exigencias técnicas que se le ponen al intérprete de cine son diferentes de las que corresponden a un actor de teatro. Casi nunca las estrellas de cine son actores sobresalientes en el sentido teatral. Por lo general han sido más bien actores de segunda o tercera categoría a los que el cine ha abierto una gran carrera. En dirección contraria, son raros los mejores intérpretes de cine que han pasado del cine al escenario; el intento ha fracasado en la mayoría de los casos. (Este hecho tiene que ver con la peculiar naturaleza del cine, para el que es menos importante que el intérprete represente a otro ante el público a que se represente a sí mismo ante el sistema de aparatos.) El actor de cine típico sólo se representa a sí mismo. Está en contraposición al tipo de mimo. Este hecho limita su empleo sobre el escenario pero lo amplía extraordinariamente en los estudios de cine. La estrella de cine llega a su público sobre todo porque, a partir de él, a cada individuo parece abrírsele la posibilidad de 'entrar en el cine'. La idea de ser reproducido en un sistema de aparatos ejerce sobre el hombre actual una inmensa atracción. Anteriormente también, sin duda, cualquier muchacha se ilusionaba con subir al escenario. Pero el sueño de entrar en el cine tiene dos ventajas frente a esa ilusión: en primer lugar, es mas realizable, porque el consumo de intérpretes por el cine (donde cada intérprete sólo se actúa a sí mismo) es mucho mayor que el del teatro; en segundo lugar, es más atrevido, porque la idea de ver difundida masivamente la propia presencia, la propia voz, hace palidecer al brillo del gran actor". 
persistencia de la metáfora del atravesamiento ideal de la pantalla en el cine. En Premio de belleza (Prix de beauté, 1930) de Augusto Genina, el personaje de Louise Brooks muere, víctima de los celos de su antiguo novio, mientras se mira a sí misma, extasiada, cantando en la pantalla. En Bellissima (I95I) Visconti denuncia los ilusionismos del cine y su impacto perverso en la espectadora (Anna Magnani), por el deseo de pantalla que suscita y las consiguientes alocadas identificaciones. La mano de la madre tapando los ojos de la nińa para que no se vea a sí misma llorando en la pantalla, entre las carcajadas de los asistentes a la filmación del casting, invierte la metáfora del atravesamiento la pantalla. Frente a la humana verdad que persigue el cine neorrealista, el ilusionismo cinematográfico (y su prostitución al mercado) es ficción mistificadora. La metáfora vuelve a invertirse, en dirección de lo cómico, en $U n$ americano a Roma (1954) de Steno, cuyo protagonista se identifica con los personajes del cine hollywoodiense, que interioriza en su delirio imitativo. La secuencia inicial es metáfora del dispositivo de sugestión del cine: la cámara, en vez de acompañar la mirada de Alberto Sordi "hacia" la pantalla, penetra en su mente con las imágenes que se proyectan "desde" la pantalla (cuyo reflejo emocional vemos en su rostro). En la secuencia del visionado del casting de Fellini 81/2 (1963), el marco de la pantalla desaparece, y de ella vemos sólo las imágenes que contiene, proyectadas para espectadoras que deberían reconocerse en las aspirantes a actrices. El efecto es opuesto al de Bellissima: si en Visconti la pantalla delataba su poder distorsionador, en Fellini la supresión del marco insinúa la sospecha de que aquella ficción (actrices en el papel de la esposa y de la amante del protagonista) está dentro, y no fuera, de la realidad que representa, tan poco auténtica como sus simulacros fílmicos. Godard neutraliza la disyuntiva entre el registro cómico y el trágico en Los carabineros (Les carabiniers, 1963). Uno de lo protagonistas, soldado en un país ocupado, asiste por primera vez a la proyección de un film y reacciona como si las imágenes fuesen reales. Cuando una mujer se desnuda y entra en una bañera, él intenta traspasar la tela de la pantalla para bañarse con ella. Se trata de la misma metáfora de El moderno Sherlock Holmes, que aquí está al servicio de la denuncia de la barbarie de la guerra, entre cuyas pulsiones de muerte está también el furor iconoclasta (o sea, la reificación de las imágenes). Muy matizada es la función de la pantalla en El último espactáculo (The last picture show, 197I) de Peter Bogdanovich. Al principio, el protagonista besa a la novia en un cine, mirando El padre de la novia (Father of the Bride, 1950) de Minnelli, no para imitar a los personajes, como Keaton, sino para fantasear con Elizabeth Taylor que ocupa, en su mente, el lugar de la chica feúcha que está besando. Al final, en el mismo cine, el protagonista y su amigo, soldado que está a punto de ir a Corea, admiran a John Wayne y sus vaqueros en el final de Rio Rojo (Red River, 1948) de Howard Hawks. En Hannah y sus hermanas (Hannah and Her 
Sisters, 1986), de Woody Allen, los Hermanos Marx inspiran en Woody, desde la pantalla, tranquilizantes pensamientos sobre la existencia de Dios. Todo lo contrario ocurre en Taxi Driver (1976) de Martin Scorsese: el porno insinuado en la pantalla ofende a la chica (Cybill Shepherd) y la aleja del protagonista. Televisada, la pantalla revela identidades no verbalizadas, como en Mi viaje a Italia (Il mio viaggio in Italia, 200I), documental del propio Scorsese en el que las secuencias de Camarada (Paisà, 1946) de Roberto Rossellini revelan al niño de una familia de inmigrados en Nueva York, junto con sus raíces, los lazos entre las generaciones; o bien expresa la nostalgia de un cine que, junto con su específico y exclusivo espacio estético, ha perdido también la función ejemplar de antaño, como en Lost in translation (2003) de Sofia Coppola, en la que los dos protagonistas conversan en la cama del hotel mientras la televisión emite la secuencia de la Fontana de Trevi de La dolce vita (1960) de Fellini, con un paralelismo de situaciones que sugiere la sacralidad del deseo y la intangibilidad de su objeto. Análogamente, en la escena final de Volver (2006) de Pedro Almodóvar, la madre, que protege en secreto a las hijas fingiéndose muerta, mira en la televisión a Anna Magnani que, en Bellissima, se peina ante el espejo mientras detrás de ella, en otra habitación, el marido cuenta amorosamente a la niña la fábula de Pinocho (antídoto paterno contra el mal de pantalla de la madre). Almodóvar invierte, así, la denuncia del ilusionismo cinematográfico de Visconti: es la televisión la que ejerce ahora una nefasta influencia mistificadora. Pero la denuncia más espectacular de los "mercaderes de sueños", síntesis definitiva del simbolismo fílmico del motivo de la pantalla, genial fusión de cómico y trágico, es una secuencia del Don Quijote de Orson Wells (desgraciadamente excluida del montaje de Jesús Franco): el hidalgo, en una sala de cine, se arroja hacia la pantalla, en la que luchan soldados romanos de un peplum, y la desgarra a sablazos, hasta descubrir que detrás no hay nada.

\section{II}

Releamos ahora brevemente el episodio a la luz de la relación con la alteridad novelesca que la pareja de adúlteros experimenta en la propia experiencia de deseo. Como se recordará, después del primer sucinto relato de la aventura sentimental que la ligó al cuñado y expuso ambos a la venganza del marido, Francesca es interrogada por Dante acerca de la finalidad y el modo en que los dos amantes llegaron a conocer el uno el deseo del otro (vv. II8-I2O):

Ma dimmi: al tempo d'i dolci sospiri, a che e come concedette amore che conosceste i dubbiosi disiri? 
[mas di: en los días de suspiros dulces ¿en qué y cómo Amor os permitió el descubrir deseos tan inciertos?]

La pregunta pone en evidencia uno de los elementos de la ética del deseo que más preocupa al poeta, o sea su manifestación verbal, que representa, más allá de la pura satisfacción sexual, el objetivo primario de la tensión de amor, cultivada por la poesía en tanto que fuente de inspiración y, por lo tanto, motor de la expresión. ${ }^{I O}$ La pregunta que Dante le dirige a Francesca sobrentiende que la culpa de los dos amantes no consistió en el hecho de haberse deseado, siendo el deseo prerrogativa de los corazones "gentiles" (ennoblecidos por el amor) sino en haber malentendido la finalidad y las modalidades expresivas del deseo: no los ha condenado el deseo, sino los objetivos por los cuales este ha sido cultivado, y las formas con las que ha sido manifestado. Si hubiese permanecido oculto, o si se hubiese expresado en modo diferente, no habría habido ningún pecado. Por tanto, resulta esencial, para entender en qué consiste su culpa, que Francesca narre, para el poeta que la interroga y para el lector de la Commedia, la situación en que los dos amantes tuvieron conocimiento el uno del deseo del otro, y que confiese así de qué manera pudo aflorar y manifestarse lo que habría debido quedar oculto en la intimidad del corazón.

Obsérvese ahora cómo esta pregunta plantea una cuestión antropológica en la cual reconocemos una característica de nuestra cultura y de nuestra mentalidad, eso es, la dialéctica expresiva entre la experiencia interior y su manifestación verbal externa. La exigencia moral de sintonizar nuestras palabras con nuestros sentimientos representa la que podríamos definir dialéctica moral del sujeto, y es justamente acerca de tal dialéctica que Francesca es invitada a pronunciarse. En efecto, esta dialéctica adquiere dimensión trágica sobre todo en el deseo, que produce la dicotomía entre la dimensión latente o interior de la subjetividad y su dimensión manifiesta, o verbal, por el halo de pudor que envuelve todos los movimientos interiores vinculados con la sexualidad. ${ }^{\text {II }}$ Sin embargo, en la tensión poética a reconducir tal dicotomía hacia una percepción integrada de la personalidad, vemos literariamente representados los valores de la autonomía del sujeto y de la primacía ética del deseo, que de tal autonomía es el fundamento.

IO. La tradición lírica italiana de nivel alto desplaza, desde sus orígenes, la dialéctica del deseo del ámbito sexual al expresivo, es decir, del cuerpo de la amada a la palabra que verbaliza la pasión del amante (sobre este punto remito a Pinto 20I0: 99-I29). En Dante este desplazamiento se observa, por ejemplo, en el capítulo XVIII de la Vida Nueva, en el cual, preguntado sobre el objeto de su amor por Beatriz, el poeta contesta: "In quelle parole che lodano la donna mia" [las palabras que alaban a mi señora].

II. La dialéctica entre expresión y sentimiento es también una cuestión política, ya que la libertad de expresarse es uno los derechos fundamentales y originarios del hombre, reconocido como tal por las democracias modernas. 
La respuesta de Francesca, que evoca la lectura de una novela que narra los amores de Lanzarote y de la reina Ginebra, sitúa tal experiencia de lectura exactamente en el punto en que la palabra del corazón (el augustiniano "verbum cordis") debería transformarse en palabra pronunciada (el "verbum oris"). Este momento en que, leyendo, los dos cuñados se reconocen como amantes y se declaran el uno al otro, reflejados en los personajes de la novela, ocupa el lugar expresivo en que la personalidad del sujeto debería recomponerse verbalmente, sintonizando lo interno con lo externo, o sea revelando mediante las palabras al otro sus sentimientos. En lugar de decirse su amor manifestándolo directamente, y usando los recursos verbales que la cultura literaria tiene previstos (por ejemplo la lírica, que como discurso del sujeto aislado garantiza la distancia entre el yo y su objeto de deseo), Francesca y Paolo han dejado que un libro hablara por ellos, y han "copiado", según sugiere Girard, la manera de amar que allí se narra.

Ahora bien, justamente en esta función vicaria, de mediar o sustituir la expresión verbal de la experiencia interior, nosotros apreciamos el sentido más profundo de la novela moderna, cuyo discurso, a pesar de su carácter ficticio, nos sitúa y orienta en la realidad del mundo, enseñándonos a actuar en él. Podríamos decir también que gracias a la novela, aquella experiencia de deseo originaria del yo, descubierta por los líricos, adquiere su más amplia y popular difusión social en la mentalidad y en los comportamiento de los lectores. ${ }^{12}$ Pero se trata de una difusión que supone la degradación de la tensión de deseo, que consume inmediatamente su objeto en lugar de refinarse en una sublimación tanto moral como expresiva (la fin'amor de los trovadores). Dante, en efecto, no sólo intuye la originalidad histórica de la novela sentimental y de caballería, sino también denuncia su perverso potencial de degradación materialista, la amputación que la personalidad sufre cuando la sexualidad (tema novelesco privilegiado) es vivida como fin en sí misma, y no como energía al servicio de la potenciación espiritual del yo. En la identificación mimética con los personajes que actúan en la escena erótica novelesca, el deseo del lector, en lugar de sublimarse poéticamente en la palabra que lo espiritualiza y redime (las "palabras que alaban a mi señora", según el cap. XVIII de la Vida Nueva), se degrada viciosamente en la consumación sexual del objeto ("la bocca mi baciò tutto tremante”). Es necesario, sin embargo, entender que el poeta no

I2. En los triángulos novelescos, Lanzarote - Ginebra - Arturo y Tristán - Isolda - Marco se transcribe, en efecto, el triángulo lírico trobador - midons - gilos (es decir, el marido de ella). Revelador del abstracto modelo de deseo triangular que subyace tanto en la lírica como en la novela y finalmente en el cine es el hecho que la primera versión cinematográfica italiana de la historia de Paolo y Francesca (Francesca di Rimini, 19IO), de Ugo Falena e interpretada por Francesca Bertini, introduzca en el guión un elemento tristaniano: en la película Gianciotto envía a Paolo a pedir la mano de su prometida esposa, y el retorno de los futuros cuñados se produce en barco. Es en la nave donde los dos "aprenden a amarse", y durante la lectura de una novela se besan. 
rechaza la función mediadora desempeñada por la literatura, función que la poesía (al menos la suya) ejerce según un nobilísimo programa de redención cultural de la humanidad, sino su degradación novelesca, es decir, el uso perverso (digamos, incluso: acrítico) que la novela hace de tal mediación, orientando hacia abajo y no hacia arriba, hacia la materia y no hacia el espíritu, el deseo del lector.

Al denunciar el género novelesco como responsable del pecado de lujuria cometido por los dos amantes corteses, Dante abre la gran reflexión de la literatura sobre la función ejemplar de la fictio, ${ }^{13}$ y sobre la función que a la ficción es asignada, impensable antes, de elaboración de modelos culturalmente prestigiosos y socialmente operativos de comportamiento y mentalidad. Lo que sorprende y escandaliza, de la novela, es su nueva prerrogativa de autorizar valores colectivamente compartidos, función y prerrogativa que anteriormente estaban confiados al mito y a la religión, y que más tarde heredarían el cine y la televisión, las formas contemporáneas de producción de fictio. El realismo dantesco debe ser entendido en el cuadro de tal desarrollo histórico, y por tanto en un sentido densamente pragmático, no deducible de la teoría antigua (es decir, la aristotélica) sobre el realismo del arte. No se trata de reflejar la realidad, proponiendo verosímiles interpretaciones del mundo, las cuales, en tanto que verosímiles, también son modélicas. Esta teoría implica un mundo, o sea una realidad, ya dado, inalterable, que la literatura no transforma, sino simplemente refleja. De lo que se trata en la novela moderna, en cambio, es reconstruirlo ficticiamente para poderlo transformar, orientando el deseo del lector hacia actitudes pragmáticamente dispuestas a intervenir sobre la realidad. En la novela el mundo es narrado de una manera tan arbitrariamente seductora como para sugerir y autorizar comportamientos y valores que, nacidos como ficciones, puedan luego, después de la lectura, proyectarse sobre la realidad, mediando los deseos del lector, que identificándose con personajes presentados como dignos de admiración, se posiciona con ellos frente al mundo.

La idea del libro o del autor que son "galeotti" (o sea, modelos de transgresión persuasivamente propuestos al deseo mimético de los lectores) viene recogida al pie de la letra por otros dos clásicos de la literatura protomoderna, el Decameron, de Boccaccio, título que explícitamente remite al V canto del Inferno, ya que el libro es "cognominato Principe galeotto" ${ }^{4}$ (y por tanto reivindica positivamente aquella función seductora y transgresora de la literatura que Dante denuncia como perversa en la novela), y el Tirant lo Blanc, novela catalana de Joanot Martorell (I490), de la cual así escribe Cervantes:

13. Según el tratado lingüístico de Dante, De Vulgari Eloquentia II iv 2, la poesia "nichil aliud est quam fictio rethorica musicaque poita" (No es otra cosa que una ficción retórica musicalmente estructurada).

I4. "Denominado Príncipe Galeotto". 
Aquí comen los caballeros, y duermen y mueren en sus camas, y hacen testamento antes de su muerte, con estas cosas de que todos los demás libros deste género carecen. Con todo eso, os digo que merecía el que le compuso, pues hizo tantas necedades de industria, que le echaran a galeras por todos los días de su vida (I 6). ${ }^{15}$

De esta manera entendemos que Francesca es la primera de una larga serie de personajes paradigmáticos de la modernidad, personajes que vuelven a proponer, a cada cambio estético de la evolución cultural de Occidente, la misma cuestión relativa a la validez ejemplar de la fictio literaria. En el momento mismo de acusar (v. I37) a la novela y a su autor de comportarse como rufianes, ya que, hablando por los amantes, ponen al descubierto eso que debería quedar oculto, Francesca revela el auténtico contenido de su culpa. Culpa que no es otra cosa que la ley general de la modernidad, la cual consiste justamente en la substitución de la verdad mítica y religiosa, en cuanto fuentes de modelos culturales, por la fictio poética y novelesca. La imitatio Cristi cede su puesto de honor al culto laico de la literatura, la cual, a partir de la Commedia, decreta la esterilidad de la religión y el mito como modelos éticos. Y lo mismo vale, obviamente, para la mitología clásica, ya que la pasión de Francesca no sólo no es deducible de aquella de Jesús, sino que tampoco lo es de la pasión de Dido (de la cual sería absurdo imaginar que se enamore de Eneas para parecerse a una heroína de ficción). ${ }^{\mathrm{I} 6}$

\section{III}

Como se ha observado anteriormente, la propuesta teórica de Girard prevé también, en el marco de la estructura triangular del deseo, una función histórica de aproximación del mediador al sujeto, que coincide con el proceso de secularización de la cultura europea, y que puede ser reconocido en la usurpación, por parte de divos y famosos, de la función ejemplar anteriormente ejercida por personajes literarios y novelescos, y antes aún, a una distancia todavía mayor, por santos y héroes. Es dentro de este proceso que debe ser analizado

I5. Sobre las cuestiones que plantea este fragmento, remito a mi ensayo Cervantes. Irradiazioni di Francesca da Rimini nella letteratura spagnola, en Pinto 2010: 285-300.

I6. En el canto II del Infierno, a Virgilio que le propone guiarlo por el más allá, Dante contesta comparándose con Eneas y S. Pablo, representantes, respectivamente, del mito y de la religión: "Io non Enëa, io non Paulo sono" (v. 32). A ambos él se contrapone en tanto que poeta, entendiendo con ello que la función de ordenar imaginariamente el mundo, anteriormente gestionada por el mito y la religión, ahora (o sea, en la modernidad) la gestiona la literatura, cuya moderna hegemonía sobre lo imaginario no consiste simplemente en la producción de modelos profanos de identifición novelesca, sino también, y más sutilmente, en el acercamiento sub specie literaria de modelos religiosos: San Francisco se proclamaba "juglar de Dios", y san Juan de la Cruz acude a los modelos líricos más elegantes y profanos del Renacimiento para reinterpetar la palabra de Dios. En la Regenta, de Clarín, no hay diferencia de peso entre devoción religiosa y perversión erótica. 
el contenido estético del cine, cuya tecnología está al servicio de un proyecto de civilización en que el mediador del deseo se aproxima poderosamente al espectador, que puede identificarse idealmente con el modelo ficticio en una medida desconocida a cualquier forma estética anterior, desdibujándose así la línea de confín entre realidad y ficción (fenómeno que caracteriza en su conjunto la estética del novecientos). La gran literatura del siglo pasado ha evidenciado a menudo los efectos de angustioso extrańamiento que la confusión entre ficción y realidad produce, sustrayendo al yo sus tradicionales coordinadas existenciales. El cine, en cambio, que de tales procesos puede ser considerado el responsable (en cuanto dispositivo estético), ilumina los aspectos positivos del fenómeno, que consisten en una mayor capacidad de control del sujeto sobre los mecanismos de proyección e identificación del yo. El fenómeno, concomitante al radical acercamiento del mediador del deseo, es ilustrado por W. Benjamin en el ensayo ya citado, y consiste en la actitud crítica que el cine suscita en el público, por profano que éste sea en materia de técnica cinematográfica. En efecto, justamente en su espontánea y desideologizada actitud crítica se manifiesta el control que el espectador adquiere, gracias al cine, sobre los objetos de su propio deseo y en consecuencia sobre la construcción de la propia identidad individual. De este modo el cine ejecuta, en un plano de mayor amplitud y profundidad, el proyecto de civilización vehiculado por la novela moderna. Lo hace ofreciendo el divo como pasto de la famélica praxis deseante del espectador, que en el cine (o en su subrogado televisivo) busca y encuentra los modelos a los cuales inspirar, y con los cuales legitimar, la propia conducta de vida. Es más, la omnipresencia todopoderosa de la tecnología de la imagen ejerce un monopolio tan absoluto sobre la percepción estética como para neutralizar cualquier forma de legitimación, ética y política, que no sea la de la fictio audiovisual por ella producida. La conversión de la política en espectáculo muestra con evidencia este poder que la industria de lo ficticio ha adquirido.

Todo ello sugiere que entre literatura y cine existe una relación de evolución histórica (al interno de un mismo paradigma estético), más que una relación especular y de influencias temáticas (entre lenguajes estéticos diversos). Potenciando, mediante la tecnología, la percepción audiovisual de lo real, el cine incrementa el poder de atracción intramundana que la literatura modernamente ejerce sobre los valores de la trascendencia, secularizándolos completamente y, quizás, irreversiblemente. En el marco de la expresión fílmica, es el registro cómico el que empuja ulteriormente hacia adelante tales procesos de deconstrucción del mito, presentando la realidad como prolongación de la imagen e incluso como su copia degradada. ${ }^{17} \mathrm{Y}$ esto vale no sólo para los

17. Lucidísimo es, al respecto, el diagnóstico de Cesare Segre sobre el estatuto de la ficción literaria del novecientos, y sobre la dialéctica radicalmente nueva que en el siglo del cine se 
inicios del arte cinematográfico, como vemos en Keaton, ${ }^{18}$ sino también por sus desarrollos, como vemos en la obra de Woody Allen, cuyo guión en Sueños de un seductor (Play it again, Sam, 1972) está inspirado, con toda evidencia, en el film de que hemos partido. En Allen, además, la percepción del papel ejemplar de la ficción fílmica es explícito, y el registro cómico sirve justamente para denunciarla en su radicalismo estético y (anti)ideológico.

En el cine de Keaton la lógica mimética del deseo celebra su triunfo hendiendo literalmente la pantalla e invadiendo el espacio pseudosagrado del héroe, que ahora baja del pedestal literario y se convierte en cómplice o incluso en doble del sujeto-espectador. Entre la ficción fílmica y la existencia del espectador se anula cualquier rígida separación, y los dos espacios devienen transitables en ambas direcciones. En el caso de S.H.J, el hecho de atravesar la pantalla es literal, como ya se ha observado. Pero en el caso del Cameraman (1928), la imagen fílmicamente desdoblada del protagonista, en las escenas finales del film, convence a la muchacha de que él, y no el fatuo rival-antagonista, merece el premio de su amor. Lo que equivale a decir que sólo a través de la mediación fílmica, que transforma el cuerpo en imagen, el sujeto puede aspirar a entrar en el intercambio erótico, convirtiéndose a su vez en objeto de deseo, y por tanto viendo premiadas sus expectativas de realización en el mundo. Se trata, en efecto, del mismo procedimiento de traspasar la pantalla, ya que el resultado es, en ambos casos, la total y por tanto cómica abolición de cualquier distancia i de cualquier barrera que separe la sacralidad del modelo imaginario y la experiencia del sujeto deseante. Woody Allen desarrolla estas

instaura entre realidad e invención. Si bien centrada sobre lo literario, el análisis de Segre individua con exactitud la abolición de la franja separativa entre realidad y ficción (que la tecnologia de la imagen produce y reverbera en el discurso literario): "Sino al Novecento, si può dire che gli scrittori partono da concezioni empiriche ma abbastanza stabili di realtà, rivolgendosi, per trovarne gli elementi antinomici, alle sfere del religioso, del mitico, del magico, della leggenda. Col Novecento si verifica un capovolgimento: la sicurezza della realtà entra in crisi, mentre si disseccano le fonti dell'assurdo 'istituzionale' (religione, mito, etc.). La dialettica realtà / irrealtà viene dunque impiantata ex novo, e solo sul terreno della incrinata e sfuggente realtà. È per questo che nella narrativa contemporanea non è stabilita una zona precisa di pertinenza dell'irreale e del meraviglioso: divenute sfuggenti le proprietà del reale, è anche compromessa l'identificazione del suo opposto. Il meraviglioso (sempre in senso negativo: l'assurdo, l'incubo) si annida nella quotidianità, la rende ancor più impervia, nemica, incomprensibile. Se il meraviglioso tradizionale metteva in forse le leggi fisiche del nostro mondo, il meraviglioso moderno smentisce gli schemi d'interpretazione che l'uomo nella sua lunga parabola ha messo a punto per la propria esistenza. Il nuovo meraviglioso è una mimesi stralunata dall'orrore delle scoperte" (Segre 1979).

18. Junto a Keaton hay que considera a Frank Capra, que desde sus primeras experiencias como director (al servicio de Harry Langdon, para el cual dirigió y/o escribió el guión de tres films: The Strong Man, 1926; Tramp, Tramp, Tramp, 1926; Long Pants, 1927) puso en el centro de su investigación el moderno estatuto de la ficción y la mediación que ella realiza respecto al deseo del sujeto-lector-espectador. En Long pants es la lectura de novelas la que perturba la mente del protagonista lanzándolo a una alocada y cómica peripecia cuya finalidad es la conquista de la mujer de quien se ha enamorado. 
pioneras intuiciones de Keaton en La rosa púrpura del Cairo (The purple rose of Cairo, 1985), haciendo de manera que los dos protagonistas atraviesen la barrera entre realidad y ficción, el uno saliendo de la pantalla y la otra entrando en ella. Y es justamente este tránsito de la ficción a la realidad y viceversa lo que defino como "mediación cómica del deseo", ya que con ello la modernidad lleva a término aquel proyecto de identificación total y sin residuos del sujeto con su mediador, que resulta finalmente destituido de cualquier tipo de distancia y autoridad.

Me apremia ahora observar que tal identificación puede, por una parte, solamente ser fílmica, por el realismo connatural al efecto cinematográfico, ya que en el cine "vemos" las cosas, no las "imaginamos", como en la lectura;"19 y que, por otra parte, puede tan sólo ser cómica y en consecuencia preconsciente, dada la profanación del espacio de trascendencia al que cada imagen, en tanto que imagen, remite. ${ }^{20}$ En efecto, la función deconstructiva de la risa es intrínsecamente hostil a las ideologías, y lo es tanto más cuanto mayor es el uso que de las ideologías hace el poder para legitimarse. El cómico cinematográfico es por tanto el más "galeotto" de los registros expresivos, ya que el acercamiento al modelo y la eliminación de la barrera entre realidad y ficción se producen por debajo del nivel consciente y voluntario del espectador. ${ }^{21}$ Aun así se trata de una aproximación y una eliminación social y culturalmente necesarios para que el sujeto pueda, sobre las ruinas de los modelos ejempla-

19. "Non è concepibile 'vedere e sentire' la realtà nel suo succedere se non da un solo angolo visuale: e questo angolo visuale è sempre quello di un soggetto che vede e sente. Questo soggetto è un soggetto in carne ed ossa, perché anche se noi, in un film di finzione scegliamo un punto di vista ideale, e quindi in qualche modo astratto e non naturalistico, ecco che esso diviene realistico, e, al limite, naturalistico, nel momento in cui piazziamo in quel punto di vista una macchina de presa e un magnetofono: esso risulterà come qualcosa di visto $\mathrm{e}$ udito da un soggetto in carne ed ossa - cioè con occhi e orecchie" (Pasolini 1977).

20. La trascendencia de las imágenes se inscribe en la cultura humana como su más originario fundamento (léase Exodo, 20, 3-6, dónde se comenta el primer mandamiento: "No tendrás otro Dios fuera de mí", "No harás ídolo ni imagen alguna de lo que está arriba en el cielo ni de lo que está aquí abajo en la tierra, ni de lo que está en las aguas bajo tierra. No te postrarás delante de ellos y no les servirás. Porque yo, tu Señor, soy tu Dios, un Dios celoso, que castiga la culpa de los padres en los hijos hasta la tercera y la cuarta generación, para los que me odian, pero que demuestra su favor hasta mil generaciones, a aquellos que me aman y observan mis mandamientos." Advertimos en esta amenaza una alusión al antiguo poder mágico de las imágenes (poder de neutralizar las fuerzas adversas de la naturaleza a través del control icónico de ésta), poder que el único Dios del monoteísmo deconstruye acaparrando para sí todas las funciones mágicas de la trascendencia. Tal poder resurge fortalecido, sin embargo, en las modernas estrategias imaginativas del deseo, las cuales, enormemente potenciadas por la tecnología, producen la apropiación de la imagen por parte del sujeto, que la manipula adaptándola a las configuraciones de su deseo. La línea que separa el control responsable de la identidad personal del devaneo psicótico entre múltiples y caóticas proyecciones imaginativas del yo se disuelve en la misma medida en que desaparece una sólida y difusa inclinación a la crítica estética (literaria y artística).

2I. La afloración, en la comicidad, de contenidos inconscientes y reprimidos, es el tema del tratado de Freud sobre el chiste (El chiste y su relación con el inconsciente, en Freud: 200I, pp. I029-II67). 
res desautorizados por la tecnología, libremente construirse como persona. Paradójicamente, son los ridículos personajes de Buster Keaton, Frank Capra y Woody Allen los que revelan mejor que cualquier otro personaje cinematográfico (épico, trágico o melodramático) la utopía fundamental de la modernidad, es decir, la de un individuo heroicamente amo de su propio destino.

Una mediación cómica de este tipo nos indica la dirección de la superación postmoderna de la estética de la modernidad, superación que está claramente orientada hacia la integral virtualización del yo que las nuevas tecnologías promueven, identificando por completo realidad y ficción, o sea haciendo de la fictio el terreno en que el yo se construye a sí mismo y se despliega en el mundo según un proyecto vital libremente elaborado. ${ }^{22}$ Los efectos a menudo aberrantes de tal virtualización del yo, que aún no tiene en el sistema educativo el soporte institucional que oriente éticamente al ciudadano en el ejercicio de tales nuevas potencialidades y responsabilidades, ${ }^{23}$ y el consiguiente riesgo de manipulación consumista del sujeto, no deben ofuscar el objetivo progreso que las nuevas tecnologías suponen en el plano de la autonomía personal. En esta perspectiva, el concepto de "ficción" (tecnológicamente entendida) y el de "libertad" (políticamente concebida como integral democratización de la vida social) se confunden el uno con el otro, siendo la una condición de la otra. Por otra parte, la mediación cómica, que a través del cine celebra su triunfo, se presenta como núcleo utópico de la modernidad, irreducible programa de emancipación estética que subordina a la felicidad del individuo (de todos los individuos del planeta) cada ideología, y revela al fin que el punto de partida del proceso histórico que humaniza la trascendencia colmando su distancia de la realidad existencial, está representado por la dantesca Commedia, obra fundadora de la fictio moderna, cuyo título alude, al menos en uno de sus significados, a la abolición de cualquier barrera en relación con la trascendencia, o sea a una poética de decostrucción de lo divino y del principio de autoridad que a este va ligado.

\section{Bibliografía}

Alighieri, D., 1998, Divina Comedia, trad. Luis Martínez de Merlo, Madrid, Cátedra. Alighieri, D., 2003, Vida Nueva, edición de Raffaele Pinto, Madrid, Cátedra.

22. El campo de la autoconstrucción postmoderna del sujeto comprende no sólo la identidad personal (a través de la configuración de roles en los nuevos espacios de socialización en las redes sociales) sino también la materialidad biológica del cuerpo (a través de la genética y la cirugía estética).

23. La resistencia del profesorado de todos los niveles a integrar de manera orgánica los recursos de Internet a la enseñanza, representa el conservadurismo de una sociedad jerárquicamente organizada, incapaz de adaptarse a los nuevos y más profundos modelos de democracia. 
Alighieri, D., 20I2, De Vulgari Eloquentia, a cura di Enrico Fenzi, Roma, Salerno editrice.

Benjamin, W., 2003, La obra de arte en la época de su reproductibilidad técnica, edición de Antonio Álvarez Prieto, México, Itaca.

Boccaccio, G., 20II, Decamerón, edición de María Hernández Esteban, Madrid, Cátedra.

Cervantes, M., 2004, Don Quijote de la Mancha, Edición del Instituto Cervantes I605-2005, dirigida por Francisco Rico, Barcelona, Círculo de lectores.

Freud, S., 200I, Obras completas, Tomo 3 (I900-I905), Ensayos XX al XXV, trad. Luis López-Ballesteros y de Torres, Madrid, Biblioteca Nueva.

Girard, R., 1961, Mensonge romantique et verité romanesque, Paris, Grasset (1985, Mentira romántica y verdad novelesca, Barcelona, Anagrama).

Girard, R., 1978, The mimetic desire of Paolo and Francesca, en "To double business bound: Essays on Literature, Mimesis and Anthropolgy, Baltimore, The Johns Hopkins University Press, pp. I-8.

Iannucci A., 2004, "Francesca da Rimini: the movie", Dante, I, pp. 67-79.

Pasolini, P. P., I977, Osservazioni sul piano sequenza, en Id., Empirismo eretico, Milano, Garzanti, pp. 237-24I.

Pinto, R., 20Io, Poetiche del desiderio. Saggi di critica letteraria della modernità, Roma, Aracne..

Pirandello, L., 2007, Cuadernos de Serafino Gubbio operador, trad. de Elena Martínez, Madrid, Gadir.

Segre, C., I979, v. Finzione, en Enciclopedia, Torino, Einaudi, vol. 6, pp. 215-216. 
